\title{
Measurement of consumer awareness of food waste: construct development with a confirmatory factor analysis
}

Measurement of consumer awareness of food waste

Shahid Rasool

School of Management Sciences,

Ghulam Ishaq Khan Institute of Sciences and Technology, Topi, Pakistan

Roberto Cerchione

Department of Engineering, University of Naples Parthenope, Napoli, Italy

Jari Salo

Department of Economics and Management, Faculty of Agriculture and Forestry, University of Helsinki, Helsinki, Finland

Alberto Ferraris

Management, Dipartimento di Management, Universita degli Studi di Torino,

Torino, Italy and

Laboratory for International and Regional Economics,

Graduate School of Economics and Management,

Ural'skii federal'nyi universitet imeni pervogo Prezidenta Rossii B N El'tsina,

Ekaterinburg, Russian Federation, and

Stefano Abbate

Department of Industrial Engineering, University of Naples Federico II, Napoli, Italy

\begin{abstract}
Purpose - This study aims to examine the role of hunger, environmental, economic, landfill and water shortage concerns as significant dimensions of consumer social awareness marketing in socially responsible plate food consumption.

Design/methodology/approach - To carry out their purpose, the authors validate the hypothesized model empirically through data from 1,536 households using structural equation modeling (SEM). In particular, the construct measures of the structural model have been tested by confirmatory factor analysis (CFA).

Findings - The outcome the authors came up with is coherent with the hypothesized model, and it proves a positive relationship of the five dimensions identified on consumer awareness. Moreover, the study results show the crucial role of landfill and water shortage concerns in measuring consumer awareness.
\end{abstract}

(C) Shahid Rasool, Roberto Cerchione, Jari Salo, Alberto Ferraris and Stefano Abbate. Published by Emerald Publishing Limited. This article is published under the Creative Commons Attribution (CC BY 4.0) licence. Anyone may reproduce, distribute, translate and create derivative works of this article (for both commercial and non-commercial purposes), subject to full attribution to the original publication and authors. The full terms of this licence may be seen at http://creativecommons.org/licences/by/4.0/ legalcode

The authors wish to express their warm thanks to the editor and the anonymous reviewers for their constructive comments and invaluable suggestions throughout the review process.

Compliance with Ethical Standards

Ethical Approval: This article did not receive any funding and did not employ study with animals.

Conflict of interests: The authors declare that they have no conflict of interests.

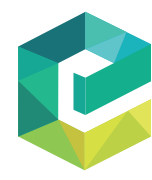

British Food Journal Vol. 123 No. 13, 2021 pp. $337-361$ Emerald Publishing Limited DOI 10.1108/BFJ-02-2021-0160 
BFJ

123,13

Practical implications - These findings may be of interest to practitioners, academics and policymakers for socially responsible food consumption guidance and training for planning consumer awareness programs. More in detail, this study offers the indication that the dimensions of the social consumer awareness construct are differing from commercial consumer awareness.

Originality/value - Even though several previous studies have addressed the concept of consumer awareness concerning product and service purchase decisions, this is one of the first research studies on consumer awareness as a multidimensional construct in social marketing studies domain.

Keywords Consumer awareness, Food consumption, Food waste, Social marketing, Structural equation modeling (SEM), Sustainability

Paper type Research paper

\section{Introduction}

Since every country is facing the issue of socially irresponsible food consumption, huge quantities of food are wasted (Food and Agricultural Organization, 2020). Notably, food loss occurs mainly during the processing stage due to climatic conditions, a lack of sufficient facilities and harmful practices, while food waste happens when people knowingly throw away nutritious food after failing to adequately plan their meals and storing food before it spoils or expires (Feijoo and Moreira, 2020). Food waste in families is far higher in volume than in businesses, leading to households being regarded as the primary source of food waste (Attiq et al., 2021). There are the ten top countries in the world that have been identified as massive wasters of food: the USA (95.1 kg, per capita), Belgium (87 kg, per capita), Canada (78.2 kg, per capita), Australia (76.3 kg, per capita), Austria (73.6 kg, per capita), Denmark (71.6 kg, per capita), Lithuania (68.5 kg, per capita), France (67.2 kg, per capita), Finland (65.5 Kg, per capita) and Italy (65.1 Kg, per capita) annually (Andrews, 2020).

In prior studies, numerous researchers have discussed food wasted at various stages (Williams et al., 2012; Iorgulescu et al., 2015; Aschemann-Witzel et al., 2015; Stancu et al., 2016; Richter, 2017; Amicarelli and Bux, 2020). Most of these works consider food that was wasted in distribution, transportation, retail and different food services (Drewitt, 2013; Jaaffar, 2013; Cuesta, 2014; Liu, 2014; Shashi et al., 2020). Consequently, food companies gradually integrate numerous ecological and social welfare issues into their operations while adhering to sustainable development principles (Kushwah et al., 2019c). It should also be noted that open innovation principles have been previously indicated as effective approaches to address grand challenges in the food and beverage sector (Bresciani et al., 2016; Bresciani, 2017; Bogers et al., 2020).

Consumer awareness describes the degree to which customers are alert to their responsibilities and rights in the marketplace for making purchasing decisions (Rousseau and Venter, 1993, 1995). In particular, consumer awareness is a multidimensional construct that involves bargain hunting, general consumer knowledge, product knowledge, information seeking and price awareness (Makanyeza and Du Toit, 2015). With the growing availability of environmental information, consumer awareness of environmental concerns is increasing (Kim, 2017). An ethical consumer is a worried person about environmental issues, human rights, animal welfare and labor working conditions in developing countries (Vermeir and Verbeke, 2006). Royne et al. (2011) examined factors influencing consumers' attitudes in purchasing an environmentally friendly item, showing consumer concern for waste, biosphere, wildlife, popular issues, public health, energy and environmental technology. The authors discovered that people who place a high value on waste reduction are willing to spend more money on an environmentally friendly product. Buerke et al. (2016) tested three main dimensions: environmental, social and economic consumer awareness toward sustainable consumption behavior. These three factors significantly affect social consumer behavior, such as buying a product with a fair-trade label, thus avoiding purchasing from renowned organizations for having poor working 
conditions for their employees. However, in research on socially responsible plate food consumption, scholars have not explored consumer awareness as a multidimensional construct for social marketing (Buerke et al., 2016). Instead, consumer awareness has been analyzed as an unidimension, namely hunger awareness (Seider et al., 2009), environmental awareness (Santos et al., 2013; Kong et al., 2014; Lim et al., 2014), economic awareness (Lipinski et al., 2013; Koester, 2014; Papargyropoulou et al., 2014), landfill awareness (Behera et al., 2010; Curry and Pillay, 2012; Browne and Murphy, 2013) and water shortage awareness (Kummu et al., 2012; Lundqvist et al., 2008). Based on this research gap, the present study aims to understand the factors influencing consumer awareness toward food consumption using the classifications proposed by Faith et al. (2002), Keller et al. (2006), Fujii et al. (2003), Clark et al. (2003), Wall et al. (2007) and Iscen (2015).

Furthermore, this paper aims to extend the concept of consumer awareness with the support of stimuli-organism-response (S-O-R) theory and consumer perception theory (CPT), providing new insight into consumer awareness to minimize food waste by hunger, environmental, economic, landfill and water shortage concerns. With these premises, this research aims to answer the following research question (RQ):

$R Q$. What are the influences of hunger, environmental, economic, landfill and water shortage factors on consumer social awareness toward food consumption?

The first contribution of this research is to propose a five-dimensional consumer awareness construct for socially responsible food consumption. The second contribution is developing operational measures related to the awareness of hunger, environmental, economic, landfill and water shortage concerns. As the third contribution, we provide an empirical investigation through structural equation modeling (SEM) to develop the social consumer awareness construct.

The paper is organized as follows. After this introduction, the second section presents the theoretical background. The third section discusses the research model and hypotheses. The fourth section explains the methodology and data collection, and the analysis of results is examined in the fifth section. The sixth section includes a discussion of the results. Finally, we presented the conclusions and implications of the study, highlighting the research limitations and future research directions.

\section{Theoretical background}

From a generic perspective, perception refers to the senses that any organism uses to collect information about its environment (Mostert, 1996). However, perception in consumer behavior implies a more complex field than mere biological senses since it includes the interaction and integration of stimuli by the consumer (Mostert, 1996). In consumer behavior, the scientific literature provides numerous definitions to explain the concept of perception. For example, Walters (1989) argues that "perception refers to the entire process by which an individual becomes aware of the environment and interprets it so that it will fit into his or her frame of reference." Therefore, the CPT concerns the impression and awareness of the customer concerning a company or its offerings, allowing evaluating how to improve consumers' benefit perception (Sun et al., 2020).

Furthermore, in the scientific literature, the S-O-R theory is primarily adopted to explain consumer behavior. This theory was developed by Mehrabian and Russell (1974), and it is based on environmental psychology. According to the S-O-R theory, several external or environmental elements can operate as stimuli (S), influencing an organism's internal state (O) and hence shaping its behavioral response (R). Therefore, the organism reflects the internal processes and structures that act as an intermediary between external stimuli and the consumers' final response (Kumar et al., 2021a). Previous research has used the S-O-R
Measurement of consumer awareness of food waste 
BFJ

123,13

340

theory in different contexts. For instance, Konuk (2019) examined how food quality, price fairness, perceived value and customer satisfaction influence consumers' plans to return and spread word-of-mouth about organic food restaurants. Similarly, Tandon et al. (2021) examined consumers' claimed purchasing behavior toward organic food consumption. Quoquab et al. (2020) analyzed the influence of the halal logo on trust, perceived reputation and customer loyalty. Goyal and Goyal (2021) investigated the impact of perceived customer effectiveness to green brand trust on green consumption intentions. Furthermore, in the context of information technology, the theory has been applied to analyze the social impact of the online learning environment (Zhai et al., 2019; Kumar et al., 2021a). As a result, the S-O-R theory is particularly suited to the goal of our study because it employs external social stimuli to influence the consumer's internal state and shape his behavior, which is socially led and reflected in his decisions and actions.

\section{Research model and hypotheses}

The research model for this study was developed by applying the CPT theory and S-O-R theory to the context of socially responsible food consumption. This framework is crucial to assess the influence of external stimuli (i.e. hunger, environmental, economic, landfill and water shortage concerns) on consumer awareness of food consumption, thus affecting the consumer's internal state and shaping his purchasing behavior.

\subsection{Hunger concern}

The hunger concept is typically used interchangeably with food insecurity (Paslakis et al., 2021). Holben (2005) explained the concept of hunger by combining a large number of definitions. However, several definitions developed one with four-dimensional hunger definition (Holben, 2005): (1) a motivational drive, (2) an uneasy sensation felt when one has no food for some time, (3) discomfort feelings, weakness, illness or pain, which is brought about a prolonged as well as involuntary lack of food, and (4) the prolonged, involuntary lack of food itself. Moreover, FAO (2016) reported that in 2014-2016, approximately 795m people of the 7.3bn people in the world, namely one out of nine, were suffering from undernourishment. Practically all the starving people, $780 \mathrm{~m}$, live in developing countries with $12.9 \%$, or one out of eight, of the developing countries population. Thus, more or less $11 \mathrm{~m}$ people undernourished are located in developed countries (FAO, 2014; IFPRI, 2015). Regarding causes of hunger intensity globally, few potential cases have been identified in the existing literature: poverty trap, lack of investment in agriculture, climate and weather, war and displacement, unstable markets and food wastage (WFP, 2016). Food waste is attached with a debatable issue where hunger among the poor is still common (FAO, 2014). Recent public attention and global initiatives to battle global hunger and improve food security have increased the issue of food loss and waste reduction (Porat et al., 2018). Researchers report 24, 24 and $35 \%$ of food losses in processing, postharvest and consumption stadiums in the food supply chains (Chauhan et al., 2021). Further, one of the most significant Sustainable Development Goals (SDGs) is to reduce malnutrition and hunger (Duro et al., 2020), and food waste is one of the core elements to decrease hunger in the world. Neff et al. (2015) highlighted increased consumer awareness toward food waste prevention strategies to improve food security, nutrition, budgets, environment and public health. Recent research has also shown an increased awareness and changes in consumer behavior towards food consumption due to the pressure of SDG 2 (end hunger) and SDG 12 (ensure sustainable consumption and production patterns) (Jribi et al., 2020). Consequently, according to the S-O-R theory and CPT theory, it is expected that consumers with a high level of perception of hunger concerns are more likely to have a high degree of awareness of food waste challenges. The studies 
presented above support a relationship between hunger concern and social consumer awareness. Therefore, the following hypothesis is developed:

H1a. Hunger concern is a significant dimension of social consumer awareness

\subsection{Environmental concern}

Environmental concerns are described as the degree to which consumers are aware of environmental damage (Dhir et al., 2021a). Wastage of food is one of the major sources of environmental pollution (Dhir et al., 2020; Chauhan et al., 2021). Globally, food waste is producing several gases that proved detrimental to the environment (FAO, 2014). In terms of greenhouse gas (GHG) emissions, the food that is lost is associated with around 1.5 gigatons of $\mathrm{CO}_{2}$ equivalent every year (FAO, 2020). Furthermore, several other gasses produced from food waste such as nitrogen $\mathrm{N} 2$, nitrous oxide $\mathrm{N}_{2} \mathrm{O}$, nitrogen dioxide $\mathrm{NO}_{2}$ and ammonia $\mathrm{NH}_{3}$ (Nielsen et al., 2003; Grizzetti et al., 2015).

According to Dhir et al. (2020), food waste can be divided into three categories: (1) avoidable waste, (2) unavoidable waste and (3) potentially avoidable food waste. In particular, avoidable food waste is once nutritious but has become inedible when it enters the landfill. On another note, unavoidable waste refers to items that are not edible, such as eggshells. Finally, potentially avoidable food waste is described as waste that is occasionally eaten, such as potato skins.

Aomari (2014) explained that now consumers are tremendously conscious of the significant changes for the planet and accept and make a gesture favoring the environment. At this stage, socially responsible consumption is only at its beginning, and it is collectively responsible, progressive and increasing consumer awareness to respect environmental degradation. Organic food is an example of socially responsible consumption. To meet the increasing demand for organic food, the practice of organic farming and the availability of organic food have increased (Kushwah et al., 2019a). Consumers perceive organic food as more environmentally friendly and healthier than traditional food (Tandon et al., 2021). Consequently, the primary organic food consumption's motivators include food safety, environmental protection, nutritional value and the absence of dangerous additives (Kushwah et al., 2019b). In addition to organic food, consumers are becoming more interested in local food due to its link to environmental sustainability (Kumar et al., 2021b). In particular, local food is characterized by production in small quantities, originating within 10-100 miles of its consumption, with low use of chemicals and different ecological benefits (Kumar et al., 2021b).

Kumar et al. (2021a) demonstrated that customer behavior toward natural products, including food, is highly influenced by health consciousness and environmental concerns. Furthermore, consumers exhibit more excellent knowledge and awareness of environmental issues (Dhir et al., 2021b). Thus, the consumer does socially responsible food consumption in response to environmental stimuli, and we proposed the following hypothesis:

H1b. Environmental concern is a significant dimension of social consumer awareness

\subsection{Economic concern}

Recent research revealed that food waste results in an economic loss of $23 \%$ of the food purchased (Papargyropoulou et al., 2019; Dhir et al., 2020). Moreover, food waste has different types of economic losses, such as cost of food production, cost of wasted food management and cost of human health due to food waste decreases. According to the first one, the Food and Agriculture Organization (FAO, 2014) reported that food wasted ranges from $30 \%$ to $40 \%$ of the overall annual production. In monetary value, the average house wasted the food equivalent to 470 pounds a year, which enhances this amount to 700 pounds of the family with children. The amount of food waste in the USA reached 162bn dollars in 2015 
BFJ

123,13

342

(FAO, 2016). Approximately $3 \mathrm{~m}$ barrels of oil are used per year to produce electricity for cultivating food in the USA. In the end, most of that food is not consumed (Francis, 2016; Hall et al., 2009). However, compared to social and environmental challenges, the economic dimension of sustainable consumption has received less emphasis, even if it is fundamental for advancing society's economic well-being (Buerke et al., 2016). According to Buzby et al. (2011) and Morone et al. (2019), food waste generates significant inequity, poverty and many economic losses worldwide. Consequently, consumer awareness toward responsible production and consumption is increasing, and it is essential to achieve long-term sustainability (Buerke et al., 2016). In line with the CPT theory, the growing consumer awareness will lead to socially responsible companies that reduce food waste and the associated economic losses. Hence, the following hypothesis is proposed:

H1c. Economic concern is a significant dimension of consumer social awareness

\subsection{The landfill concern}

The landfill is known as the coverage of land with waste disposal that may not be reused, recycled and recovered (Scottish Environment Protection Agency, 2016). Where there is several side effects of food waste, the landfill is one of them (Gunders, 2012). Many leftovers, forgotten produce and prepared and packaged meals have been sent to the landfills. Therefore, large heaps of garbage are boiling at the localities' boundaries (Gunders, 2012). Environmental Protection Agency (2010) stated that wasted food is the sole most significant component of the solid waste sourced from landfill. The wasted food consists of uneaten food and food preparation leftovers from houses, commercial establishments such as restaurants, institutional sources such as schools such as colleges and university cafeterias (Zhang et al., 2007). The main issue with landfill is that it occupies a portion of the potential agricultural land that can grow the food for human survival (Nunley, 2013).

Bloom (2010) studied that a massive quantity of food is wasted due to consumer socially irresponsible consumption disposed of in the landfills. Gunders (2012) stated that large heaps of garbage consisted of food waste reaching landfill and incineration started, which transformed into methane gasses. Morgan (2009) disclosed that each year 4.2m tons of food waste in Australia ends up in landfill due to their irresponsible consumption behavior, and almost $2.7 \mathrm{~m}$ tons of wasted food from socially irresponsible household consumers and $1.5 \mathrm{~m}$ from the irresponsible consumer at commercial places such as hotels, motels and restaurants. In particular, the hospitality sector is considered the third-biggest contributor to global food waste (Sharma et al., 2021).

Saeed et al. (2009) revealed that Malaysia is one of those countries producing a massive quantity of food waste from production to consumer consumption stage. Otitoju and Seng (2014) examined that nearly $70 \%$ of solid waste is disposed of by using landfill method in Sarawak Malaysia. The major component of $70 \%$ solid waste is food waste $(50 \%)$, resulting from irresponsible food consumption by the consumer at various places such as households, restaurants, hostels, cafeterias and hotels. However, this problem has also occurred in other countries. Santos et al. (2012) highlighted that Brazilian restaurants demonstrated little environmental awareness and violated trash disposal requirements by failing to separate recyclables from nonrecyclables. The high amount of food waste generation and becoming part of landfill cause most issues such as foul odor, toxic leachate and GHG emissions (Al-Rumaihi et al., 2020). Consumer awareness toward the increased waste in landfills led companies to adopt sustainable practices and technologies in their activities (Leaver, 2008). Moreover, according to the FAO (2011), increased awareness can help minimize household food waste. Indeed, higher awareness of food waste and its environmental impact leads to better purchase behaviors, lower food waste generation and lower waste in landfills (Parizeau et al., 2015). It is expected that consumers who have a high level of perception of 
landfill concerns are more likely to have a high degree of awareness toward food waste, in line with the S-O-R theory. Therefore, in light of the proposed notions, we put forward the following hypothesis:

H1d. The landfill concern is a significant dimension of consumer social awareness
Measurement of consumer awareness of food waste

\subsection{Water shortage concern}

Humans and their well-being require water as a primary resource (Vörösmarty et al., 2010). Consequently, water shortage is one of the primary issues in the list of world issues that are predicted to be principal challenges to human populations (Uchtmann, 2011). According to Lee et al. (2020), water scarcity challenges have been compounded by recent fast population increase, economic development and compounded disaster risk, as well as climate change. Notably, Rijsberman (2007) discussed the issue of water shortage as follows: "The world water crisis has caught us unawares, with a series of local hydrological pinch-points rapidly escalating into a global pandemic of empty rivers, dry boreholes, and wrecked wetlands as profound as, and often linked to, climate change."

The comprehension of world water shortage crises may be seriously enlarged by investigating the three types of crisis such as safe drinking water, pollution and degradation and water scarcity (Lal, 2008). Firstly, safe drinking water involves water from impurity and microorganisms, which commonly cause disease or death (Watkins, 2006). The impurity of drinking water limits human progress. About half of the entire population in the developing world suffers from health problems due to purification and water scarcity (Watkins, 2006). Secondly, water pollution is also a source of water shortage. Water pollution can be subdivided into point sources and nonpoint sources. Point sources mean wastage of water from leakage of pipe, nonpoint source due to overirrigation such as farms. Thirdly, water scarcity refers to a situation "when the water supply is inadequate concerning the water demand for basic human and ecological necessities, including the production of food and other economic goods" (Lal, 2008).

Furthermore, about 550 trillion liters of water are successfully caused to flow to irrigate the food field to grow that is never eaten (Pope, 2016). Yeomans (2012) stated that consumers are limited to aware of the shortage of water globally because there are approximately $2.6 \mathrm{bn}$ people who lack better sanitation, and about $800 \mathrm{~m}$ people do not have access to drinking water. Therefore, the scarcity of water resources poses a serious threat to humanity's survival, has inhibited national economic development and has become a global geopolitical concern (Ait-aoudia and Berezowska-Aazzag, 2016; Zhang et al., 2019; Hou et al., 2021). Guli and Yampolsky (2014) suggested that raising awareness of water shortage is one of the best ways to make responsible water consumption to combat the water scarcity in the world. The government of China is disseminating the awareness to the consumer to make responsible consumption of water. Consumers may make direct socially responsible water consumption to cope with water scarcity in the world and consume water in a socially responsible way through responsible consumption of food. Since clean water is used and often in stunning imbalance to the final product: one kilogram of beef required 15,000 liters of water, a single cup of coffee, 140 liters; and a burger 2,400 liters (Guli and Yampolsky, 2014). According to GómezLlanos et al. (2020), the water footprint is a suitable indicator for highlighting responsible water use knowledge, increasing consumer awareness about sustainable water consumption. Moreover, Garcia and Pargament (2015) emphasize the importance of providing a communication channel for stakeholders in the urban water cycle to improve decisionmaking. According to S-O-R theory and CPT theory, this agreement would increase public awareness of the current challenges in water management, thus affecting the consumer's internal state and shaping his behavior. Therefore, the following hypothesis is proposed:

H1e. Water shortage concern is a significant dimension of consumer social awareness 
BFJ

123,13

344

\section{Methodology}

In this study, a descriptive two-stage survey method was conducted to examine the factors affecting consumer awareness toward food consumption in Malaysia, that is, a pilot study and a questionnaire survey (QS). Therefore, both a pilot QS among the target population and semistructured interviews with experts in the research domain were initially conducted (Linderbaum and Levy, 2010). Subsequently, we proceeded with the QS, supporting the collection of quantitative data in a standardized manner and ensuring that it was internally consistent and coherent for the use of analytical procedures (Durdyev et al., 2018).

The pilot test was a small-scale preliminary study carried out to assess the reliability of the data and the feasibility of the experiment. It was necessary to enhance the study design before a large-scale QS was carried out in order to prevent wasting time and money on a project that was not well designed. For the pilot study, Cronbach's alpha reliability test was used to determine the accuracy of the answers. Indeed, coefficient alpha is the fundamental statistical to determine the reliability based on internal consistency (Churchill, 1979). A minimum Cronbach's alpha of 0.6 is required for the pilot study, as Hinton et al. (2004) recommended. Indeed, the reliability is weak below 0.6, acceptable under 0.7, and when the value is more than 0.8, it is excellent (Sekaran, 2003). As a result, an actual alpha of 0.85 was calculated in the pilot test, allowing us to proceed with the data collection phase.

Furthermore, before administering the questionnaire to respondents, we interviewed three professors of the University of Malaysia working on sustainability in the food industry. The purpose was to receive feedback on (1) the clarity and comprehensiveness of dimensional definitions based on their knowledge of food consumption literature and (2) the clarity and legibility of items. Subsequently, once the pilot study and expert interviews have been completed successfully, we were able to conduct the comprehensive full-scale validation study.

\subsection{Population}

The household members are selected as a target population that could understand the questionnaire for accurate response. Administratively, Malaysia comprises 13 states and three federal territories. However, it is hard to reach every member of the population of Malaysia, totaling 32.455 million people (www.worldpopulationreview.com, 2019). Hence, the researcher identified an accessible portion of the population of Malaysia. The time, resources and ease of access to the population by the researcher are the bases for this selection (Yount, 2006). Similar target and sampling population techniques have been used in research focusing on China and India, where countries are divided into regions, for example, North, South, East and West (Bryant et al., 2019).

\subsection{Sampling technique and sample size}

Furthermore, significant cities of Sarawak state of Malaysia were selected as a defined population; the major cities were relatively more correlated than the rest of this country's cities for the survey. The population was the four major cities of Kuching, Sibu, Bintulu and Miri. From each city, an appropriate sample size was collected. For the representative sample of the population, a sample of 1,536 consumers was allocated to the four major cities on a proportionate quota.

\subsection{Measures}

The assessment of hunger concern awareness questions is quite limited in marketing research, especially when it is related to plate food behavior. The existing items available in 
the literature do fit the purpose of this study (Faith et al., 2002; Keller et al., 2006). Therefore, this study needed only to develop items on hunger concern awareness. Hence, five new items were generated and aligned with consumer hunger awareness constructs. The face validity of these newly constructed items was tested during the pretest stage, and construct validity was tested during the analysis stage. The reliability was tested during and pilot test stage as well as during the analysis stage. Five items use a five-point Likert-type scale, anchored from highly unaware (1) to highly aware (5) (Table 1).

Environmental awareness items were developed from a combination of three studies, that is, Fujii et al. (2003), Clark et al. (2003) and Wall et al. (2007). Six items were adopted from these studies.

The economic awareness construct scale is developed by adopting from Wall et al. (2007). The scale was developed to measure consumer awareness related to the consequences of car usage on environmental pollution. This study adopted the five items and transformed them into consumer awareness related to food waste consequences.

Landfill awareness refers to the covering of land with waste. The evaluation of landfill awareness toward food waste instrument showed minimum availability in social science studies. Several studies were based on landfill public awareness, but those studies could not
Measurement of consumer awareness of food waste

\begin{tabular}{|c|c|}
\hline Dimensions & Items \\
\hline \multirow[t]{5}{*}{ Hunger concern } & HC_1 = Hungry people are increasing rapidly in the world \\
\hline & HC_2 = Children are more affected by the scarcity of food \\
\hline & HC_3 = There are many people around me who are food insecure \\
\hline & HC_4 = Most of the people have knowledge about hungry people \\
\hline & HC_5 = Several organizations are working to relieve world hunger \\
\hline \multirow{7}{*}{$\begin{array}{l}\text { Environmental } \\
\text { concern }\end{array}$} & ENC_1 $=$ The effects of pollution on public health are likely to be worse than I realize \\
\hline & ENC_2 = Pollution generated in one country harms people all over the world \\
\hline & $\begin{array}{l}\text { ENC_3 = Households hardly know the environmental problems caused by food } \\
\text { waste }\end{array}$ \\
\hline & $\begin{array}{l}\text { ENC_ } 4=\text { Avoiding food waste helps to solve environmental problems like global } \\
\text { warming }\end{array}$ \\
\hline & ENC_5 = Food consumption level can have an impact on the environment \\
\hline & ENC_6 = Over food consumption level contributes to environmental pollution \\
\hline & $\begin{array}{l}\text { ENC_ } 7=\text { Avoiding plate food waste can help to solve community food waste } \\
\text { problem }\end{array}$ \\
\hline \multirow[t]{5}{*}{ Economic concern } & $\begin{array}{l}\text { ECC_1 } 1=\text { Consumer purchasing choices can have an impact on the good imports of a } \\
\text { country }\end{array}$ \\
\hline & ECC_2 = Over consumption contribute to high prices of food \\
\hline & ECC_3 = I can help to control the prices of food by avoiding wastage \\
\hline & ECC_4 = Over consumption increasing prices of goods \\
\hline & $\begin{array}{l}\text { ECC_5 = Avoiding food waste helps to solve economic problem like price } \\
\text { increments of goods }\end{array}$ \\
\hline \multirow[t]{6}{*}{ Landfill concern } & LFC_1 = Useable land will gradually be covered with waste \\
\hline & LFC_2 = The waste disposal companies are dumping waste into the sea \\
\hline & LFC_3 = There are several companies responsible for properly waste disposing \\
\hline & $\begin{array}{l}\mathrm{LFC}_{\text {_ }} 4=\text { The land is continuously covered with garbage caused by household's } \\
\text { waste }\end{array}$ \\
\hline & LFC_5 = The coverage of land with food waste is harmful to the environment \\
\hline & LFC_6 = The increasing landfill is threatening the environment's natural beauty \\
\hline Water shortage & WTC_ $1=$ Drinking water is very costly \\
\hline \multirow[t]{4}{*}{ concern } & WTC_2 = Price of drinking water is increasing \\
\hline & WTC_3 = The world is facing a problem of water shortage \\
\hline & WTC_4 = People are dying due to water shortage in the world \\
\hline & WTC_5 = People have to travel a lot further to get drinking water \\
\hline
\end{tabular}

Table 1.

Scales of hunger, environmental, economic, landfill and water shortage concerns 
$\mathrm{BFJ}$

123,13

346

verify the reliability and validity of the instruments. Moreover, nonreliable and nonvalidated items were mismatched with the aims of consumer landfill awareness toward food waste. However, this study developed the landfill awareness instrument to attain reliable and valid items that represent consumer landfill awareness.

Water shortage awareness refers to water scarcity in the world (Iscen, 2015). Iscen (2015) developed the waters scarcity/shortage instrument for three dimensions: water protection, water scarcity and water pollution and water reeducation. Iscen (2015) measured the water scarcity instrument using an 11-point Likert scale from 0 to 10 . Therefore, this study adopted the five items from Iscen (2015) and converted them into a five-point Likert scale anchored from highly unaware (1) to highly aware (5).

\section{Analysis and results}

\subsection{Exploratory factor analysis for hunger concern awareness}

Exploratory factor analysis (EFA) was deployed to measure the hunger concern awareness constructs. Overall, five items were used to measure the hunger concern awareness construct. In initial results, the Kaiser-Meyer-Olkin (KMO) value was 0.733 and Bartlett's test of sphericity value was 1741.760 ( $\mathrm{df}=10$ and $p=0.000$ ), which were significant for the EFA. The results suggested that $\mathrm{HC} \_4$ had a low communality value of 0.189 from a threshold value of 0.40 . Also, item HC_4 had a lower correlation $(r=0.284)$ with other hunger concern awareness constructs. Thus, item HC_1 was excluded from the second round of EFA. In response to the exclusion of $\mathrm{HC} 4$, new results found with a new $\mathrm{KMO}$ value of 0.72 .492 , Bartlett's test of sphericity was $1658.066(\mathrm{df}=6$ and $p=0.000)$ and explained $72.492 \%$ of the variance.

Factor loading for the entire hunger concern awareness construct is acceptable, with the highest loading of 0.91 and the lowest loading of 0.72 . For the verification of good internal consistency of the sample data, the Cronbach's alpha value for the hunger concern awareness construct was 0.83 .

\subsection{Exploratory factor analysis for environmental concern awareness}

The measure of environmental concern awareness was analyzed by utilizing the EFA. The measure consisted of seven items. In initial findings, the KMO value was 0.759 and Bartlett's test of sphericity value was $1,043(\mathrm{df}=21$ and $p=0.000)$, which are significant for EFA of environmental concern awareness construct. The initial EFA also suggested a two-factor solution for the seven items. Factor 2 comprised three items, and two items ENC_1 and ENC_2 had cross-loading with factor 1 . In the second round of EFA, cross-loaded items ENC_1 and ENC_2 were excluded from the analysis. The results of second-round EFA suggested one-factor recorded an eigenvalue above 1 (2.497), which explained a total of $49.935 \%$ of the variance. The communality of item ENC_3 was 0.029, which is less than 0.4 and also had a lower correlation $(r=0.053)$ with other items of environmental concern awareness measure. Owing to that third round of EFA was performed without ENC_3 and found a KMO value of 0.770 ; Bartlett's test of sphericity was 722.123 ( $\mathrm{df}=6$ and $p=0.000$ ) and explained $61.986 \%$.

Factor loading for the entire environmental concern awareness construct is acceptable, with the highest loading of 0.86 and the lowest loading of 0.73 . For the verification of good internal consistency of the sample data, the Cronbach's alpha value for the environmental concern awareness construct was 0.79 .

\subsection{Exploratory factor analysis for economic concern awareness}

EFA was deployed to measure economic concern awareness. It was measured with five items. In initial results, the KMO value was 0.745 and Bartlett's test of sphericity was 709.107 
( $\mathrm{df}=10$ and $p=0.000$ ). EFA suggested a one-factor solution for the five items of economic concern awareness constructs. Item ECC_1 had a low communality value of 0.340 and lower correlation $(r=0.243)$ with other items of economic concern awareness measure. In the second round of EFA, Item ECC 1 was removed to fill the basic threshold of EFA. Thus, the results of the second round of EFA found a significant value of KMO at 0.722 and Bartlett's test of sphericity at $751.012(\mathrm{df}=6$ and $p=0.000)$. Moreover, the eigenvalue was above 1 (2.285), which explained $57.114 \%$ of the variance.

Factor loading for the entire economic concern awareness construct is acceptable, with the highest loading of 0.80 and the lowest loading of 0.65 . For the verification of good internal consistency of the sample data, the Cronbach's alpha value for the economic concern awareness construct was analyzed with the value of 0.75 .

\subsection{Exploratory factor analysis for landfill concern awareness}

The landfill concern awareness construct was measured with EFA. This construct consisted of six items. In initial results, The KMO value was 0.797, and Bartlett's test of sphericity was $699.685(\mathrm{df}=15$ and $p=0.000)$. Thus, data is appropriate for EFA. One factor solution was found with an eigenvalue above 1 (2.637), which explained $50.337 \%$ of the variance for six items suggested by EFA. The community of item LFC_2 and LFC_3 was 0.181 and 0.390 , which is less than the threshold value of 0.40 (Field, 2006). The second round of EFA was performed without items LFC_2 and LFC_3. The results suggested a one-factor solution with an eigenvalue above 1 (2.244), which explained $56.100 \%$ of the variance for four items.

Factor loading for four landfill concern awareness constructs is acceptable, with the highest loading of 0.80 and the lowest loading of 0.66 . For the verification of good internal consistency of the sample data, the Cronbach's alpha value for the landfill concern awareness construct was analyzed with the value of 0.74 .

\subsection{Exploratory factor analysis for water shortage concern awareness}

The water shortage concern awareness construct was measured by using the EFA. The KMO value was 0.753 , and Bartlett's test of sphericity was 815.512 ( $\mathrm{df}=10$ and $p=0.000$ ). Hence, data was suitable to utilize EFA for this construct (Table 2). One factor solution was found with an eigenvalue above 1 (2.637), which explained $52.747 \%$ of the variance for five items suggested by EFA. Factor loading for the entire water shortage concern awareness construct is acceptable, with the highest loading of 0.79 and the lowest loading of 0.60 . For the verification of good internal consistency of the sample data, the Cronbach's alpha value for the water shortage concern awareness construct was 0.77 .

\subsection{Confirmatory factor analysis}

5.6.1 Measurement model. A first-order CFA model for consumer awareness was designed (Table 3) to verify the relationship among five subdimensions of consumer awareness (Hunger Concern, Environmental Concern, Economic Concern, Landfill Concern and Water Shortage Concern) and their observed indicators (Figure 1). In initial findings, consumer awareness pooled confirmatory factor analysis consisted of 22 observed variables. The model had good fit with $x^{2}$ value of $645.788(\mathrm{df}=195$ and $p=0.000$ ), CMIN/DF of 3.312 and RMSEA of 0.062 . According to MIs suggestion, the measurement model might be improved due to higher CMIN/DF and RMSEA. In an ad hoc attempt, ECC_2 and WTC_5 factors were excluded to improve the fitness indices one by one. Both factors had a negative effect on the fitness of the model. Therefore, Items ECC_2 of economic concern and WTC_5 of water shortage concern were required to remove from the consumer awareness pooled CFA.
Measurement of consumer awareness of food waste 


\begin{tabular}{|c|c|c|c|c|c|c|c|c|c|}
\hline $\begin{array}{l}\mathrm{BFJ} \\
123,13\end{array}$ & Factor & Factor 1 & Factor 2 & Factor 3 & Factor 4 & Factor 5 & $\begin{array}{l}\text { Factor } \\
\text { loading }\end{array}$ & $\begin{array}{l}\text { Variance } \\
\text { explained }\end{array}$ & $\begin{array}{c}\text { Reliability } \\
\text { analysis } \\
\text { (Cronbach's } \alpha \text { ) }\end{array}$ \\
\hline 348 & Hunger concern & $\begin{array}{l}\mathrm{HC} \_1 \\
\mathrm{HC} \_2 \\
\mathrm{HC} \_3 \\
\mathrm{HC} \_5\end{array}$ & & & & & $\begin{array}{l}0.90 \\
0.86 \\
0.72 \\
0.91\end{array}$ & $72.492 \%$ & 0.87 \\
\hline & $\begin{array}{l}\text { Environmental } \\
\text { concern }\end{array}$ & & $\begin{array}{l}\text { ENA_4 } \\
\text { ENA_5 } \\
\text { ENA_6 } \\
\text { ENA 7 }\end{array}$ & & & & $\begin{array}{l}0.76 \\
0.86 \\
0.73 \\
0.79\end{array}$ & $61.986 \%$ & 0.79 \\
\hline & $\begin{array}{l}\text { Economic } \\
\text { concern }\end{array}$ & & & $\begin{array}{l}\text { ECC_2 } \\
\text { ECC_3 } \\
\text { ECC_4 } \\
\text { ECC_5 }\end{array}$ & & & $\begin{array}{l}0.65 \\
0.80 \\
0.76 \\
0.80\end{array}$ & $57.114 \%$ & 0.75 \\
\hline & Landfill concern & & & & $\begin{array}{l}\text { LFC_1 } \\
\text { LFC_4 } \\
\text { LFC_5 } \\
\text { LFC } 6\end{array}$ & & $\begin{array}{l}0.66 \\
0.78 \\
0.80 \\
0.74\end{array}$ & $56.100 \%$ & 0.74 \\
\hline $\begin{array}{l}\text { Table } 2 \text {. } \\
\text { Summary of results of } \\
\text { exploratory factor } \\
\text { analysis }\end{array}$ & $\begin{array}{l}\text { Water shortage } \\
\text { concern }\end{array}$ & & & & & $\begin{array}{l}\text { WTC_1 } \\
\text { WTC_2 } \\
\text { WTC_3 } \\
\text { WTC_4 } \\
\text { WTC_5 }\end{array}$ & $\begin{array}{l}0.71 \\
0.76 \\
0.79 \\
0.70 \\
0.60\end{array}$ & $52.747 \%$ & 0.77 \\
\hline
\end{tabular}

Consequently, model was improved from $x 2$ value of 645.788 ( $\mathrm{df}=195$ and $p=0.000$ ) to $457.625(\mathrm{df}=157$ and $p=000)$.

In this study, the consumer awareness model had 20 observed variables. The number of observed variances and covariances $(19[20+1] / 2)$ was 190 , and the number of estimated parameters in the model was 51 (19 regression weights, 13 covariances and 19 variances). According to the $t$-rule (Awang et al., 2015), the measurement model for consumer awareness was overidentified (the number of observed variances and covariances $>$ than the number of estimated parameters) and tested with 139 degrees of freedom (190-51).

The construct reliability (C.R) values and average variance extracted (AVE) of each subdimension (Hunger Concern, Environmental Concern, Economic Concern, Landfill Concern and Water Shortage Concern) of consumer awareness are summarized in Table 3. The composite constructs reliability for the five subdimensions ranged from 0.74 to 0.87 , which were above the recommended threshold of 0.60 as suggested by Nunnally (1978). Therefore, these values indicating that the measures for the three subdimensional factors were appropriate reliability.

Overall factor loadings were statistically significant $(t$-value $>1.96)$ and ranged from 0.50 to 0.96 (Table 3), which were above the recommended threshold of 0.40 as suggested by (Hair et al., 2006), recommending proper convergent validity. Moreover, the AVEs range from 0.37 to 0.64 , which were below acceptable ranged from 0.56 to 0.59 instead of three subdimensions (hunger concern, environmental concern and economic concern). The AVEs value less than 0.50 is acceptable, while composite C.R is higher than 0.6 (Fornell and Larcker, 1981; Hair et al., 2011). Therefore, composite constructs reliability and AVEs showing that the measures for the five-dimensional factors had accurate convergent validity.

The range of correlation coefficients of the five subdimensions was 0.30-0.84 (Figure 1 and Table 3), below the recommended level of 0.85 accords with Kline (2005). These values indicated that measures of these five subdimensions had suitable discriminant validity. 


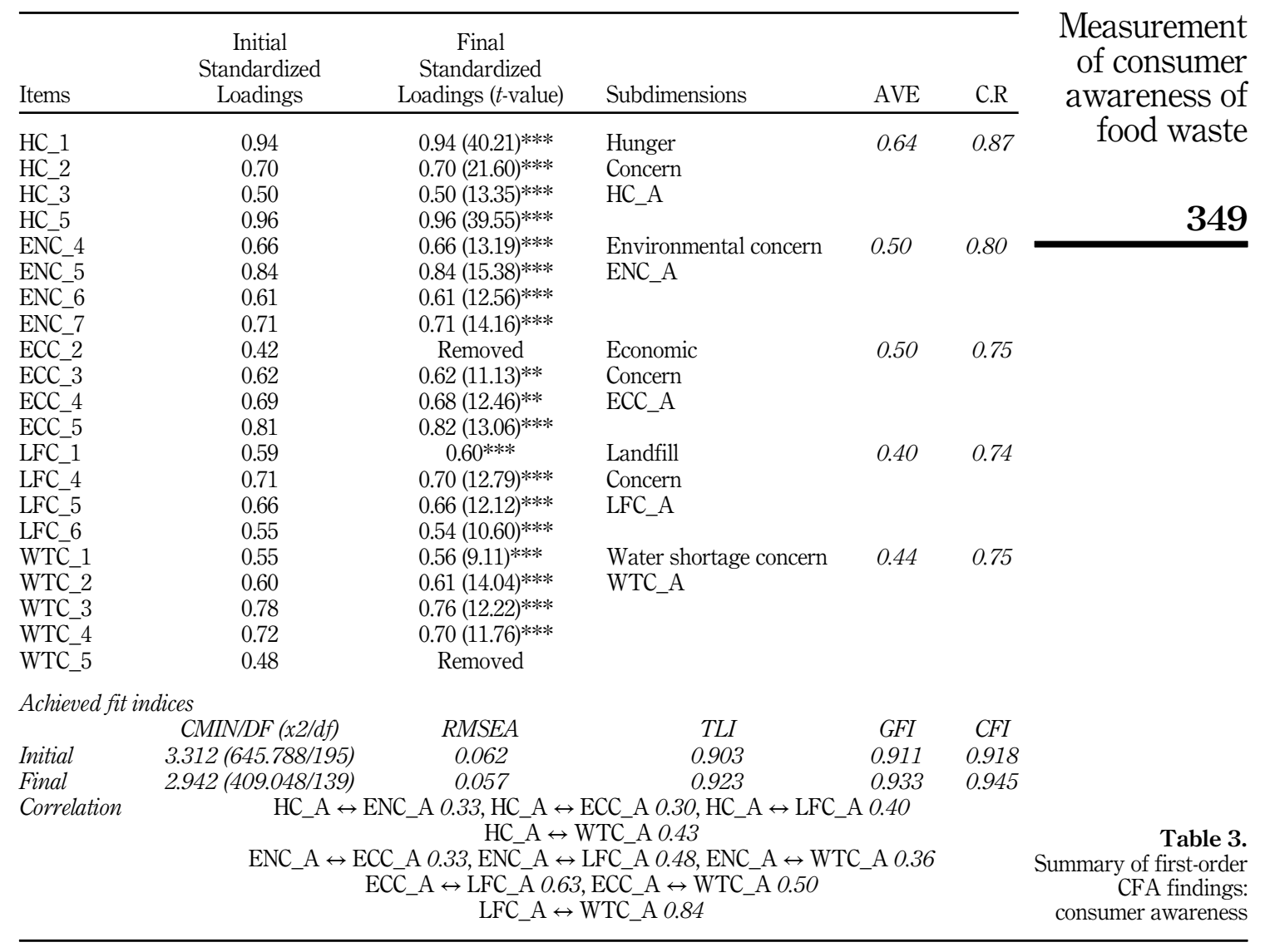

5.6.2 Second-order confirmatory factor analysis model for consumer awareness. We test the relationships between five subdimensions (Hunger concern, Environmental concern, Economic concern, Landfill concern and Water shortage concern) and one primary dimension of consumer awareness in second-order CFA (Figure 2). There are 19 observed variables presented in the model. The number of variances and covariances $[19(19+1) / 2]$ was 190 data points, and the number of estimated parameters in the model was 46 (19 regression weights, 3 covariance and 25 variances and residual). According to the $t$-rule (Awang et al., 2015), the measurement model for consumer awareness was overidentified (the number of observed variances and covariance $>$ than the number of estimated parameters) and tested with 144 degrees of freedom (190-46).

At initial consumer awareness results, the second-order CFA model had good model fitness to the sample data. All the recommended thresholds for model fit indices were adequately satisfied with an $x^{2}$ value of $430.982(\mathrm{df}=144$ and $p 0.000), \mathrm{CMIN} / \mathrm{DF}$ of 2.992 and RMSEA of 0.058; the rest of the indices were shown in Table 3. Thus, a modification for model fitness was not necessary. The goodness of fit of consumer awareness second-order CFA is summarized in Table 4 and Figure 2. 
$\mathrm{BFJ}$

123,13

350

Figure 1.

Pooled first-order confirmatory factor analysis model for consumer awareness

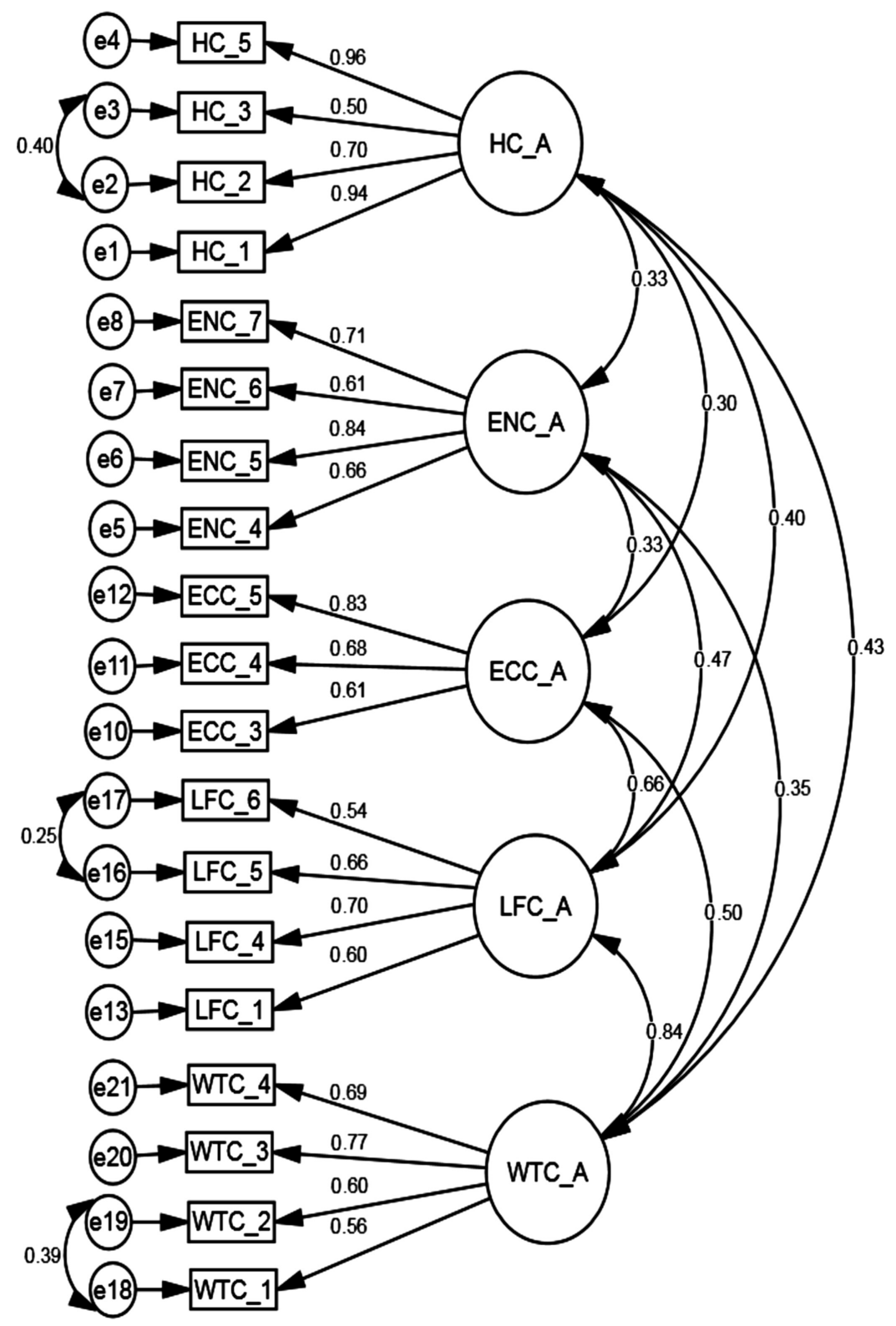

\section{Discussion}

This study aimed to analyze the factors influencing social consumer awareness and the influences of these factors on social consumer awareness toward food consumption. To achieve this aim, a sample of consumers who have their food on the plate at the household level was selected. Surveying this population of food consumers allowed us to understand the role of hunger, environmental, economic, landfill and water shortage concerns as significant 


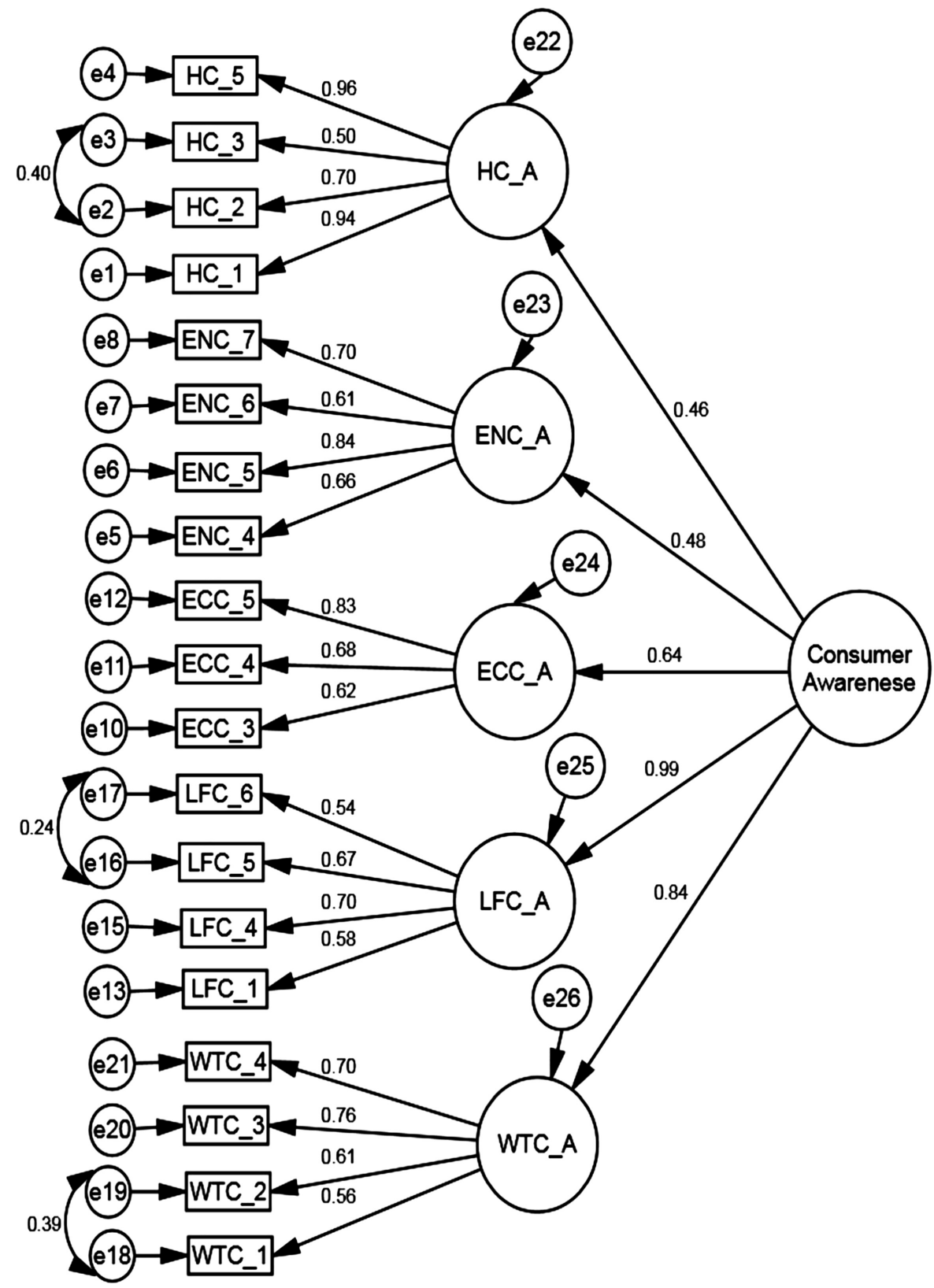

Measurement of consumer awareness of food waste

Figure 2.

Second-order confirmatory factor analysis model for consumer awareness

dimensions of consumer social awareness about socially responsible plate food consumption. This study also explored the relationship among the five factors identified and answered the influence of those factors on consumer awareness empirically.

The measurement model results for consumer awareness supported hypothesis H1a, H1b, H1c, H1d, H1e and confirmed the five subdimensions of consumer awareness, which were 


\begin{tabular}{|c|c|c|c|c|c|c|}
\hline $\begin{array}{l}\text { BFJ } \\
123,13\end{array}$ & Items & $\begin{array}{c}\text { Final } \\
\text { Standardized loading }\end{array}$ & (t-value) & Subdimensions Of consumer awareness & AVE & C.R \\
\hline & HC_1 & 0.94 & 35.44 & Hunger concern & 0.64 & 0.87 \\
\hline & HC_2 & 0.70 & 21.60 & & & \\
\hline & $\mathrm{HC}_{-}^{-} 3$ & 0.50 & 13.35 & & & \\
\hline & HC_5 & 0.96 & 39.55 & HC_A & & \\
\hline 352 & ENC_4 & 0.66 & 12.30 & Environmental concern & 0.50 & 0.80 \\
\hline & $\begin{array}{l}\text { ENC_5 } \\
\text { ENC } 6\end{array}$ & 0.84 & $\begin{array}{l}15.38 \\
1256\end{array}$ & FNC A & & \\
\hline & $\begin{array}{l}\text { LNe_0 } \\
\text { ENC_7 }\end{array}$ & 0.70 & $\begin{array}{l}12.56 \\
14.16\end{array}$ & ENC_A & & \\
\hline & $\mathrm{ECC} 3$ & 0.62 & 11.15 & Economic concern & 0.50 & 0.75 \\
\hline & ECC_4 & 0.68 & 12.46 & & & \\
\hline & ECC_5 5 & 0.83 & 13.06 & ECC_A & & \\
\hline & LFC_1 & 0.58 & 10.40 & Landfill concern & 0.40 & 0.74 \\
\hline & LFC_4 & 0.70 & 12.79 & & & \\
\hline & LFC_5 & 0.67 & 12.12 & LFC_A & & \\
\hline & LFC_6 & 0.54 & 9.23 & & & \\
\hline & WTC_1 & 0.56 & 10.60 & Water shortage concern & 0.44 & 0.75 \\
\hline & WTC_2 2 & 0.61 & 14.04 & & & \\
\hline & WTC_-3 & 0.76 & 12.22 & WTC_A & & \\
\hline & WTC_4 & 0.70 & 11.76 & & & \\
\hline $\begin{array}{l}\text { Table } 4 . \\
\text { Summary of initial }\end{array}$ & Fit indices & & & & & \\
\hline findings (second-order & & $C M I N / D F\left(x^{2} / \mathrm{df}\right)$ & RMSEA & $T L I$ & $G F I$ & CFI \\
\hline CFA): consumer & Initial/Final & $2.992(430.982 / 144)$ & 0.058 & 0.930 & 0.908 & 0.941 \\
\hline & Note(s): $C . R$ & $=$ Composite Reliabilit & $A V E=A$ & erage Variance Extracted & & \\
\hline
\end{tabular}

significant positive relationships between each other. This study highlights that consumers tend to evaluate their awareness by assessing the five primary dimensions in socially responsible plate food consumption. The results are different from those proposed by Makanyeze and Du Toit (2015) and Du Plessis (2007). These previous studies reveal significant positive relationships between the five dimensions (i.e. bargain hunting, general consumer knowledge, product knowledge, information search, price consciousness) of marketing to social marketing dimensions (i.e. hunger concern, environmental concern, economic concern, landfill concern, water shortage concern). However, this study is the first to provide a comprehensive overview of consumer awareness dimensions in the domain of social marketing.

The results of the empirical investigation show that the landfill concern subdimension is the most significant indicator in quantifying consumer awareness of socially responsible plate food consumption. This result is consistent with the research conducted by Makanyeze and Du Toit (2015), Du Plessis (2007) and Du Plessis et al. (1994), whose studies also uncovered a significant relationship among five dimensions (i.e. bargain hunting, general consumer knowledge, product knowledge and price consciousness) of the consumer awareness for commercial marketing. Therefore, it was found that landfill concern subdimension of consumer awareness is an essential predictor for socially responsible plate food consumption.

Secondly, the water shortage concern is the second significant indicator in measuring consumer awareness of socially responsible plate food consumption. The economic concern is the third important subdimension of consumer awareness concerning socially responsible plate food consumption. This result assured that the economic concern subdimension has a significant positive relationship with consumer awareness, and also this result is consistent with the previous studies of Makanyeze and Du Toit (2015) and Du Plessis (2007). 
The environmental concern is the fourth significant predictor of consumer awareness for socially responsible plate food consumption. Finally, hunger concern is the fifth significant predictor of consumer awareness for socially responsible consumption plate food consumption.

The results of this research can be explained by the growing pressure of the Agenda 2030 and its 17 SDGs on public opinion (United Nations, 2015). In this broad program, food seems to have been a cross-cutting issue, which links most of the goals; indeed, without eliminating hunger, ensuring food and nutrition security and improving the global population's health, the Agenda 2030 cannot be successfully implemented (Peano et al., 2019). As a result, nowadays, there is an increasing awareness of environmental issues, particularly food consumption issues (Dhir et al., 2020). According to Chylinska-Wrzos et al. (2015), consumers are paying growing attention to the food items they buy, such as organic goods, which are becoming increasingly common thanks to the lower environmental impact they generate.

\section{Conclusions and implications \\ 7.1 Contribution to theory}

The outcomes of this research can be used to generate various imperatives for both academics and practitioners. The current study has different theoretical contributions. First, this research extends previous literature in which consumer awareness has been analyzed as a unidimensional construct (Seider et al., 2009; Lim et al., 2014; Papargyropoulou et al., 2014; Browne and Murphy, 2013; Kummu et al., 2012). The novelty of this study is in the multidimensional construct of consumer awareness in the field of social marketing studies. In particular, we offer a five-dimensional consumer awareness framework for socially responsible food consumption. The second contribution is creating operational measures to raise awareness about hunger, environmental, economic, landfill and water shortage issues. Specifically, we tested these measures in the context of socially responsible food consumption by consumers. The final contribution is an empirical analysis of the social consumer awareness construct using structural equation modeling, revealing that hunger, environmental, economic, landfill and water shortage concerns represent significant dimensions of consumer social awareness marketing in socially responsible plate food consumption.

\subsection{Contribution to practice}

This study offers key inputs for different stakeholders. These include scholars, practitioners, marketers and policymakers. First, the findings of this study can call food marketing managers' attention to the importance of the five dimensions suggested for socially responsible food consumption guidance and training. In particular, our results show the crucial role of landfill and water shortage concerns in measuring consumer awareness. Consumer education is at the heart of a branding strategy since consumer decision behavior and ethical purchasing intentions are strongly influenced by information (Kushwah et al., 2019c). As a result, managers should develop adequate consumer awareness programs and marketing campaigns to guide them toward the purchase of sustainable products, such as organic food. Customer perceptions are generally affected by publicity, reviews, public relations, social networks and personal experiences. Consequently, companies should strengthen their marketing communication strategies to improve consumers' benefit perception and change their purchase intentions (Sun et al., 2020). For example, in their promotional efforts, practitioners can create a positive image of organic foods by emphasizing that their consumption is fairer, wiser and more environmentally friendly than standard foodstuffs, reducing water consumption and landfill waste. In this way, food
Measurement of consumer awareness of food waste 
BFJ

123,13

companies could increase sales and profit margins. Moreover, due to the growing attention to the SDGs, policymakers and governments working on sustainable consumption initiatives should use the findings of our study in promoting sustainable and ethical consumption activities, thus encouraging populations to buy environmentally friendly items, reducing waste and environmental pollution. According to Chauhan et al. (2021), policymakers should also make it mandatory for managers to develop time-bound plans to effectively execute and monitor food loss and waste reduction goals.

\subsection{Limitations and future directions}

While the current study has given newer insight into the organic consumption community, it presents few limitations that should be considered in future studies. Firstly, the sample of ours includes 1,536 households in Malaysia. However, a comparison of two diverse countries will help to explain the underlying differences in consumption behaviors in the studied sample (Kushwah et al., 2019c). Thus, a future investigation may be regarding further analysis in different countries to test our findings in different geographic contexts. Crosscountry investigation could help enhance the generalizability of our findings (e.g. Ferraris et al., 2019). Second, this paper aims to examine the primary factors influencing consumer awareness toward sustainable food consumption. Consequently, future studies could explore barriers toward socially responsible plate food consumption. Furthermore, a future research direction concerns evaluating the enabling role of different key Industry 4.0 technologies, such as the Internet of things and Blockchain, to evaluate food waste more traceably and transparently (Centobelli et al., 2020). These technologies could significantly enhance food safety by allowing items to be identified, tracked and traced at all supply chain stages (Akyazi et al., 2020). In the end, since the growing importance of value-adding activities in the social marketing domain, another exciting challenge may be inherent in adapting the research model in different local systems and evaluate the impact on individual firms and sustainable supply chains.

\section{References}

Ait-Aoudia, M.N. and Berezowska-Aazzag, E. (2016), "Water resources carrying capacity assessment: the case of Algeria's capital city”, Habitat International, Vol. 58, pp. 51-58.

Akyazi, T., Goti, A., Oyarbide, A., Alberdi, E. and Bayon, F. (2020), "A guide for the food industry to meet the future skills requirements emerging with industry 4.0", Foods, Vol. 9 No. 4, 492.

Al-Rumaihi, A., McKay, G., Mackey, H.R. and Al-Ansari, T. (2020), "Environmental impact assessment of food waste management using two composting techniques", Sustainability (Switzerland), Vol. 12 No. 4, 1595.

Amicarelli, V. and Bux, C. (2020), "Food waste measurement toward a fair, healthy and environmentalfriendly food system: a critical review", British Food Journal, available at: https:/www.emerald. com/insight/content/doi/10.1108/BFJ-07-2020-0658/full/html.

Andrews, C. (2020), "Countries that waste the most food", available at: https://247wallst.com/specialreport/2019/09/10/countries-that-waste-the-most-food/4/.

Aomari, A. (2014), "The responsible consumption: factor of the development of environmental responsibility in Morocco", Journal of Economics, Business and Management, Vol. 2 No. 3, pp. 219-223.

Aschemann-Witzel, J., De Hooge, I., Amani, P., Bech-Larsen, T. and Oostindjer, M. (2015), “Consumerrelated food waste: causes and potential for action”, Sustainability, Vol. 7 No. 6, pp. 6457-6477.

Attiq, S., Danish Habib, M., Kaur, P., Junaid Shahid Hasni, M. and Dhir, A. (2021), "Drivers of food waste reduction behaviour in the household context", Food Quality and Preference, Vol. 94, 104300 . 
Awang, Z., Afthanorhan, A. and Asri, M.A.M. (2015), "Parametric and non parametric approach in structural equation modeling (SEM): the application of bootstrapping, modern applied science", Modern Applied Sciences, Vol. 9 No. 9, pp. 132-133.

Behera, S.K., Park, J.M., Kim, K.H. and Park, H.S. (2010), "Methane production from food waste leachate in laboratory-scale simulated landfill”, Waste Management, Vol. 30 No. 8, pp. 1502-1508.

Bloom, J. (2010), American Wasteland: How America Throws Away Nearly Half of its Food (And what We Can Do about it), Da Capo Lifelong Books, London.

Bogers, M., Chesbrough, H. and Strand, R. (2020), "Sustainable open innovation to address a grand challenge : lessons from Carlsberg and the green fiber bottle", British Food Journal, Vol. 122 No. 5, pp. 1505-1517.

Bresciani, S. (2017), "Open, networked and dynamic innovation in the food and beverage industry", British Food Journal, Vol. 119 No. 11, pp. 2290-2293.

Bresciani, S., Ferraris, A., Santoro, G. and Nilsen, H.R. (2016), "Wine sector: companies' performance and green economy as a means of societal marketing", Journal of Promotion Management, Vol. 22 No. 2, pp. 251-267.

Browne, J.D. and Murphy, J.D. (2013), "Assessment of the resource associated with biomethane from food waste", Applied Energy, Vol. 104 April, pp. 170-177.

Bryant, C.J., Szejda, K., Deshpande, V., Parekh, N. and Tse, B. (2019), "A survey of consumer perceptions of plant-based and clean meat in the USA, India, and China", Frontiers in Sustainable Food Systems, Vol. 3, pp. 1-11.

Buerke, A., Straatmann, T., Lin-Hi, N. and Müller, K. (2016), "Consumer awareness and sustainabilityfocused value orientation as motivating factors of responsible consumer behavior", Review of Managerial Science, Vol. 11 No. 4, pp. 959-991.

Buzby, J.C., Hyman, J., Stewart, H. and Wells, H.F. (2011), “The value of retail-and consumer-level fruit and vegetable losses in the USA", Journal of Consumer Affairs, Vol. 45 No. 3, pp. 492-515.

Centobelli, P., Cerchione, R., Esposito, E. and Oropallo (2020), "Surfing Blockchain wave, or drowning? Shaping the future of distributed ledgers and decentralized technologies", Technological Forecasting and Social Change, Vol. 165, 120463.

Chauhan, C., Dhir, A., Akram, M.U. and Salo, J. (2021), "Food loss and waste in food supply chains. A systematic literature review and framework development approach", Journal of Cleaner Production, Vol. 295, 126438.

Churchill, G.A. Jr (1979), “A paradigm for developing better measures of marketing constructs”, Journal of Marketing Research, Vol. 16 No. 1, pp. 64-73.

Chylinska-Wrzos, P., Lis-Sochocka, M., Wawryk-Gawda, E., Bulak, K. and Jodlowska-Jedrych, B. (2015), "Do you know what you eat? Students of the Medical University of Lublin and food consumption awareness", Current Issues in Pharmacy and Medical Sciences, Vol. 28 No. 4, pp. 260-263.

Clark, C.F., Kotchen, M.J. and Moore, M.R. (2003), "Internal and external influences on proenvironmental behavior: participation in a green electricity program", Journal of Environmental Psychology, Vol. 23 No. 3, pp. 237-246.

Cuesta, J. (2014), "Food waste: doing the math", available at: https://blogs.worldbank.org/voices/foodwaste-doing-math.

Curry, N. and Pillay, P. (2012), "Biogas prediction and design of a food waste to energy system for the urban environment”, Renewable Energy, Vol. 41 No. 1, pp. 200-209.

Dhir, A., Talwar, S., Kaur, P. and Malibari, A. (2020), "Food waste in hospitality and food services: a systematic literature review and framework development approach", Journal of Cleaner Production, Vol. 270, 122861.

Dhir, A., Koshta, N., Goyal, R.K., Sakashita, M. and Almotairi, M. (2021a), "Behavioral reasoning theory (BRT) perspectives on E-waste recycling and management", Journal of Cleaner Production, Vol. 280, 124269.

Measurement of consumer awareness of food waste 
$\mathrm{BFJ}$ 123,13

Dhir, A., Sadiq, M., Talwar, S., Sakashita, M. and Kaur, P. (2021b), "Why do retail consumers buy green apparel? A knowledge-attitude-behaviour-context perspective", Journal of Retailing and Consumer Services, Vol. 59, 102398.

Drewitt, T. (2013), Food Waste Prevention in Quick Service Restaurants, (Master Thesis), Lund University, San Francisco.

Du Plessis, M. (2007), "The role of knowledge management in innovation", Journal of Knowledge Management, Vol. 11 No. 4, pp. 20-29.

Du Plessis, P.J., Rousseau, G.G. and Blem, N.H. (1994), Consumer Behavior: Strategic Marketing Applications, 2nd ed., Southern Book, Halfway Housea.

Durdyev, S., Ismail, S., Ihtiyar, A., Abu Bakar, N.F.S. and Darko, A. (2018), "A partial least squares structural equation modeling (PLS-SEM) of barriers to sustainable construction in Malaysia", Journal of Cleaner Production, Vol. 204, pp. 564-572.

Duro, J.A., Lauk, C., Kastner, T., Erb, K.-H. and Haberl, H. (2020), "Global inequalities in food consumption, cropland demand and land-use efficiency: a decomposition analysis", Global Environmental Change, Vol. 64, 102124.

Environmental Protection Agency (2010), "Landfills”, available at: https://archive.epa.gov/epawaste/ noaz/municipal/web/html/landfill.htmletfile/collection/p15738coll2/id/130442/filename/ 130653.pdf.

Faith, M.S., Kermanshah, M. and Kissileff, H.R. (2002), "Development and preliminary validation of a silhouette satiety scale for children”, Physiology and Behaviour, Vol. 76 No. 2, pp. 173-178.

FAO (2011), "Global food losses and food waste: extent, causes and prevention", available at: http:// www.fao.org/3/a-i2697e.pdf.

FAO, I. (2014), WFP, the State of Food Insecurity in the World 2014 Strengthening the Enabling Environment for Food Security and Nutrition, Food and Agriculture Organization (FAO), Rome.

FAO, I. (2016) WFP (2015), "The state of food insecurity in the world 2015", Meeting the 2015 International Hunger Targets: Taking Stock of Uneven Progress, Rome, Food and Agriculture Organization Publications.

FAO, I. (2020), Food Loss and Waste Must Be Reduced for Greater Food Security and Environmental Sustainability, available at: http://www.fao.org/news/story/en/item/1310271/icode/.

Feijoo, G. and Moreira, M.T. (2020), "Fostering environmental awareness towards responsible food consumption and reduced food waste in chemical engineering students", Education for Chemical Engineers, Vol. 33, pp. 27-35.

Ferraris, A., Del Giudice, M., Grandhi, B. and Cillo, V. (2019), "Refining the relation between causerelated marketing and consumers purchase intentions", International Marketing Review, Vol. 37 No. 4, pp. 651-669.

Field, A. (2006), Discovering Statistics Using SPSS, 2nd ed., Sage Publication, London.

Fornell, C. and Larcker, D.F. (1981), "Evaluating structural equation models with unobservable variables and measurement error", Journal of Marketing Research, Vol. 18, pp. 39-50.

Francis, P. (2016), "Pope condemns paradox of guns but no food in conflict zones", available at: http:// www.dw.com/en/pope-condemns-paradox-of-guns-but-no-food-in-conflict-zones/a-19327736.

Fujii, Y., Kohno, M., Matoba, S., Motoyama, H. and Watanabe, O. (2003), "A 320 k-year record of microparticles in the Dome Fuji, Antarctica ice core measured by laser-light scattering (scientific paper)", Memoirs of National Institute of Polar Research, Vol. 57 No. 1, pp. 46-62.

Garcia, X. and Pargament, D. (2015), "Reusing wastewater to cope with water scarcity: eco- nomic, social and environmental considerations for decision-making", Resources, Conservation and Recycling, Vol. 101, pp. 154-166.

Gómez-Llanos, E., Durán-Barroso, P. and Robina-Ramírez, R. (2020), "Analysis of consumer awareness of sustainable water consumption by the water footprint concept", Science of the Total Environment, Vol. 721, 137743. 
Goyal, M. and Goyal, R.K. (2021), "Confirming antecedents of green consumption intention: a sustainable model for food aggregators", IETE Journal of Research, Vol. 1, pp. 1-12.

Grizzetti, B., Passy, P., Billen, G., Bouraoui, F., Garnier, J. and Lassaletta, L. (2015), "The role of water nitrogen retention in integrated nutrient management: assessment in a large basin using different modelling approaches”, Environmental Research Letters, Vol. 10 No. 6, p. 065008.

Guli, M. and Yampolsky, R. (2014), "Urbanization and its impact on China's water resources", available at: http://www.paulsoninstitute.org.cn/wp-content/uploads/2015/05/Thirst-Paper121014_vF.

Gunders (2012), "Wasted: how America is losing up to 40 percent of its food from farm to fork to landfill”, available at: https:/www.nrdc.org/sites/default/files/wasted-food-IP.pdf.

Hair, J.F.J., Black, W., Babin, B.J. and Anderson, R.E. (2006), "Multivariate data analysis", Technometrics, Vol. 31 No. 3, p. 245.

Hair, J.F., Ringle, C.M. and Sarstedt, M. (2011), "PLS-SEM: indeed a silver bullet”, Journal of Marketing Theory and Practice, Vol. 19 No. 2, pp. 139-152.

Hall, K.D., Guo, J., Dore, M. and Chow, C.C. (2009), "The progressive increase of food waste in America and its environmental impact”, Plos One, Vol. 4 No. 11, p. e7940.

Hinton, P.R., Brownlow, C., McMurray, I. and Cozens, B. (2004), SPSS Explained, Routledge, New York, NY.

Holben, D.H. (2005), The Concept and Definition of Hunger and its Relationship to Food Insecurity, Nationalacademies. org, New York.

Hou, C., Wen, Y., Liu, X. and Dong, M. (2021), "Impacts of regional water shortage information disclosure on public acceptance of recycled water - evidences from China's urban residents", Journal of Cleaner Production, Vol. 278, p. 123965.

IFPRI (2015), “International food policy research institute”, available at: http://ebrary.ifpri.org/utils/g.

Iorgulescu, R.I., Polimeni, J.M. and Balan, M. (2015), "Bioeconomic sustainability and modelling energy systems", Progress in Industrial Ecology, an International Journal, Vol. 9 No. 1, pp. 46-59.

Iscen, C.F. (2015), "Water awareness scale for pre-service science teachers: validity and reliability study”, Educational Research and Reviews, Vol. 10 No. 7, pp. 957-966.

Jaaffar, J. (2013), Food Waste Figures that Will Eat You up, New Straits Times, available at: http:// www.nst.com.my/opinion/columnist/food-waste-figures-that-will-eat-you-up 1.322683.

Jribi, S., Ben Ismail, H., Doggui, D. and Debbabi, H. (2020), “COVID-19 virus outbreak lockdown: what impacts on household food wastage?", Environment, Development and Sustainability, Vol. 22 No. 5, pp. 3939-3955.

Keller, K.L., Assur, S.A., Torres, M., Lofink, H.E., Thornton, J.C., Faith, M.S. and Kissileff, H.R. (2006), "Potential of an analog scaling device for measuring fullness in children: development and preliminary testing”, Appetite, Vol. 47 No. 2, pp. 233-243.

Kim, J.E. (2017), "Fostering behaviour change to encourage low-carbon food consumption through community gardens", International Journal of Urban Sciences, Vol. 21 No. 3, pp. 364-384.

Kline, T.J.B. (2005), Psychological Testing: A Practical Approach to Design and Evaluation, Sage Publications, Thousand Oaks, Calif.

Koester, U. (2014), "Food loss and waste as an economic and policy problem", Intereconomics, Vol. 49 No. 6, pp. 348-354.

Kong, D., Ytrehus, E., Hvatum, A.J. and Lin, H. (2014), "Survey on environmental awareness of Shanghai college students", Environmental Science and Pollution Research International, Vol. 21 No. 23, pp. 13672-13683.

Konuk, F.A. (2019), "The influence of perceived food quality, price fairness, perceived value and satisfaction on customers' revisit and word-of-mouth intentions towards organic food restaurants", Journal of Retailing and Consumer Services, Vol. 50, pp. 103-110.
Measurement of consumer awareness of food waste 
$\mathrm{BFJ}$ 123,13

Kumar, S., Dhir, A., Talwar, S., Chakraborty, D. and Kaur, P. (2021a), "What drives brand love for natural products? The moderating role of household size", Journal of Retailing and Consumer Services, Vol. 58, 102329.

Kumar, S., Murphy, M., Talwar, S., Kaur, P. and Dhir, A. (2021b), "What drives brand love and purchase intentions toward the local food distribution system? A study of social media-based REKO (fair consumption) groups", Journal of Retailing and Consumer Services, Vol. 60, p. 102444.

Kummu, M., De Moel, H., Porkka, M., Siebert, S., Varis, O. and Ward, P.J. (2012), "Lost food, wasted resources: global food supply chain losses and their impacts on freshwater, cropland, and fertiliser use", Science of the Total Environment, Vol. 438 No. 2, pp. 477-489.

Kushwah, S., Dhir, A. and Sagar, M. (2019a), "Understanding consumer resistance to the consumption of organic food. A study of ethical consumption, purchasing, and choice behaviour", Food Quality and Preference, Vol. 77, pp. 1-14.

Kushwah, S., Dhir, A., Sagar, M. and Gupta, B. (2019b), "Determinants of organic food consumption. A systematic literature review on motives and barriers", Appetite, Vol. 143, p. 104402.

Kushwah, S., Dhir, A. and Sagar, M. (2019c), "Ethical consumption intentions and choice behavior towards organic food. Moderation role of buying and environmental concerns", Journal of Cleaner Production, Vol. 236, p. 117519.

Lal, R. (2008), "Soils and sustainable agriculture. A review", Agronomy for Sustainable Development, Vol. 28 No. 1, pp. 57-64.

Leaver, G. (2008), "Wasted opportunities”, Chemical Engineer, Vol. 803, pp. 34-35.

Lee, H., Son, J., Joo, D., Ha, J., Yun, S., Lim, C.H. and Lee, W.K. (2020), "Sustainable water security based on the SDG framework: a case study of the 2019 Metro Manila Water Crisis", Sustainability (Switzerland), Vol. 12 No. 17, 6860.

Lim, W.M., Yong, J.L.S. and Suryadi, K. (2014), “Consumers' perceived value and willingness to purchase organic food", Journal of Global Marketing, Vol. 27 No. 5, pp. 298-307.

Linderbaum, B.A. and Levy, P.E. (2010), "The development and validation of the feedback orientation scale (FOS)", Journal of Management, Vol. 36 No. 6, pp. 1372-1405.

Lipinski, B., Hanson, C., Lomax, J., Kitinoja, L., Waite, R. and Searchinger, T. (2013), "Reducing food lost and waste", available at: https://pdf.wri.org/reducing_food_loss_and_waste.pdf.

Liu, G. (2014), "Food losses and food waste in China", available at: https://www.oecd-ilibrary.org/ docserver/5jz5sq5173lqen.pdf?expires $=1537871011 \& i d=i d \& a c c n a m e=$ guest\&checks.

Lundqvist, J., de Fraiture, C. and Molden, D. (2008), "Saving water: from field to fork: curbing losses and wastage in the food chain", available at: http://dlc.dlib.indiana.edu/dlc/bitstream/handle/ 10535/5088/PB_From_Filed_to_Fork_2008.pdf?sequence=1\&isAllowed=y.

Makanyeza, C. and Du Toit, F. (2015), "Examining the measurement and dimensionality of the construct of consumer awareness in a developing and transition economy", Journal of Industrial Psychology, Vol. 41 No. 1, p. 9.

Mehrabian, A. and Russell, J.A. (1974), An Approach to Environmental Psychology, The MIT Press.

Morgan, E. (2009), Fruit and Vegetable Consumption and Waste in Australia, State Government of Victoria, Victorian Health Promotion Foundation, Victoria, pp. 1-58.

Morone, P., Falcone, P.M. and Lopolito, A. (2019), "How to promote a new and sustainable food consumption model: a fuzzy cognitive map study", Journal of Cleaner Production, Vol. 208, pp. 563-574.

Mostert, P.G. (1996), “Consumer Perceptions of Displayed Product Attributes in Advertising, MComm Dissertation, University of Pretoria, Pretoria, available at: http://upetd.up.ac.za/thesis/available/ etd- 08202009-133937/unrestricted/00front.pdf.

Neff, R.A., Spiker, M.L. and Truant, P.L. (2015), "Wasted food: U.S. consumers' reported awareness, attitudes, and behaviors", PLoS ONE, Vol. 10 No. 6, e0127881. 
Nielsen, D.L., Brock, M.A., Rees, G.N. and Baldwin, D.S. (2003), "Effects of increasing salinity on freshwater ecosystems in Australia”, Australian Journal of Botany, Vol. 51 No. 6, pp. 655-665.

Nunley, M. (2013), From Farm to Fork to Landfill: Food Waste and Consumption in America.

Nunnally, J.C. (1978), Psychometric Theory, 2nd ed., McGraw-Hill, New York, NY.

Otitoju, T.A. and Seng, L. (2014), "Municipal solid waste management: household waste segregation in Kuching South City, Sarawak, Malaysia”, American Journal of Engineering Research (AJER), Vol. 3 No. 6, pp. 82-99.

Papargyropoulou, E., Lozano, R., Steinberger, J.K., Wright, N. and bin Ujang, Z. (2014), "The food waste hierarchy as a framework for the management of food surplus and food waste", Journal of Cleaner Production, Vol. 76 No. 1, pp. 106-115.

Papargyropoulou, E., Steinberger, J., Wright, N., Lozano, R., Padfield, R. and Ujang, Z. (2019), "Patterns and causes of food waste in the hospitality and food service sector: food waste prevention insights from Malaysia”, Sustainability, Vol. 11, p. 6016.

Parizeau, K., von Massow, M. and Martin, R. (2015), "Household-level dynamics of food waste production and related beliefs, attitudes, and behaviours in Guelph, Ontario", Waste Management, Vol. 35, pp. 207-217.

Paslakis, G., Dimitropoulos, G. and Katzman, D.K. (2021), "A call to action to address COVID-19induced global food insecurity to prevent hunger, malnutrition, and eating pathology", Nutrition Reviews, Vol. 79 No. 1, pp. 114-116.

Peano, C., Merlino, V.M., Sottile, F., Borra, D. and Massaglia, S. (2019), "Sustainability for food consumers: which perception?", Sustainability (Switzerland), Vol. 11 No. 21, p. 5955.

Pope, J. (2016), The Sustainability Assessment of the South West Yarragadee Water Supply Development in Western Australia, 1st ed., Routledge, London.

Porat, R., Lichter, A., Terry, L.A., Harker, R. and Buzby, J. (2018), "Postharvest losses of fruit and vegetables during retail and in consumers' homes: quantifications, causes, and means of prevention”, Postharvest Biology and Technology, Vol. 139, pp. 135-149.

Quoquab, F., Mohamed Sadom, N.Z. and Mohammad, J. (2020), "Driving customer loyalty in the Malaysian fast food industry: the role of halal logo, trust and perceived reputation", Journal of Islamic Marketing, Vol. 11 No. 6, pp. 1367-1387.

Richter, B. (2017), "Knowledge and perception of food waste among German consumers", Journal of Cleaner Production, Vol. 166, pp. 641-648.

Rijsberman, F.R. (2007), "Water for food water for life: a comprehensive assessment of water management in agriculture", available at: https:/www.taylorfrancis.com/books/mono/10.4324/ 9781849773799/water-food-water-life-david-molden.

Rousseau, G.G. and Venter, D.J.L. (1993), "Measuring consumer awareness in a developing country", SA Journal of Industrial Psychology, Vol. 19 No. 3, pp. 6-12.

Rousseau, G.G. and Venter, D.J.L. (1995), "Measuring consumer awareness in Zimbabwe”, SA Journal of Industrial Psychology, Vol. 21 No. 1, pp. 18-24.

Royne, M.B., Levy, M. and Martinez, J. (2011), "The public health implications of consumers' environmental concern and their willingness to pay for an eco-friendly product", Journal of Consumer Affairs, Vol. 45 No. 2, pp. 329-343.

Saeed, M.O., Hassan, M.N. and Mujeebu, M.A. (2009), “Assessment of municipal solid waste generation and recyclable materials potential in Kuala Lumpur, Malaysia”, Waste Management, Vol. 29 No. 7, pp. 2209-2213.

Santos, L.L., Akutsu, R.C.C.A., Botelho, R.B.A. and Zandonadi, R.P. (2012), "Food service compliance with ISO 14001 and ISO 22000", Revista de Nutricao, Vol. 25 No. 3, pp. 373-380.

Santos, B., Romão, T., Dias, A.E. and Centieiro, P. (2013), "eVision: a mobile game to improve environmental awareness", Advances in Computer Entertainment, Springer International Publishing, pp. 380-391.

Measurement of consumer awareness of food waste

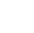


$\mathrm{BFJ}$ 123,13

Scottish Environment Protection Agency (2016), “Annual report and accounts 2015-2016”, available at: https://www.sustainabilityexchange.ac.uk/files/sepa_annual-reports-and-accounts-20152016.pdf.

Seider, B.H., Hirschberger, G., Nelson, K.L. and Levenson, R.W. (2009), "We can work it out: age differences in relational pronouns, physiology, and behavior in marital conflict", Psychology and Aging, Vol. 24 No. 3, pp. 604-613.

Sekaran, U. (2003), Research Methods for Business: A Skill Building Approach, 4th ed., John Wiley \& Sons, New York.

Sharma, R., Dhir, A., Talwar, S. and Kaur, P. (2021), "Over-ordering and food waste: the use of food delivery apps during a pandemic", International Journal of Hospitality Management, Vol. 96, 102977.

Shashi, Centobelli, P., Cerchione, R. and Ertz, M. (2020), "Food cold chain management: what we know and what we deserve", Supply Chain Management: An International Journal, Vol. 26 No. 1, pp. 102-135.

Stancu, V., Haugaard, P. and Lähteenmäki, L. (2016), "Determinants of consumer food waste behaviour: two routes to food waste", Appetite, Vol. 96, pp. 7-17.

Sun, P.C., Wang, H.M., Huang, H.L. and Ho, C.W. (2020), "Consumer attitude and purchase intention toward rooftop photovoltaic installation: the roles of personal trait, psychological benefit, and government incentives", Energy and Environment, Vol. 31 No. 1, pp. 21-39.

Tandon, A., Jabeen, F., Talwar, S., Sakashita, M. and Dhir, A. (2021), "Facilitators and inhibitors of organic food buying behavior", Food Quality and Preference, Vol. 88, p. 104077.

Uchtmann, N. (2011), "Water issues from a global, national, and local perspective”, available at: https:// global-ejournal.org/2011/09/19/water-issues-from-a-global-national-and-local-perspective/ $\mathrm{um}=$ 8CF18D51B1BCEE14EE2D71192B175EA5.

United Nations (2015), "Transforming our world: the Agenda 2030 for sustainable development", available at: https://sustainabledevelopment.un.org/content/documents/21252030\%20Agenda \% 20for \%20Sustainable\%20Development \%20web.pdf.

Vermeir, I. and Verbeke, W. (2006), "Sustainable food consumption: exploring the consumer 'attitude behavioral intention' gap”, Journal of Agricultural and Environmental Ethics, Vol. 19 No. 2, pp. 169-194.

Vörösmarty, C.J., McIntyre, P.B., Gessner, M.O., Dudgeon, D., Prusevich, A., Green, P., Glidden, S., Bunn, S.E., Sullivan, C.A., Liermann, C.R. and Davies, P.M. (2010), "Global threats to human water security and river biodiversity", Nature, Vol. 467 No. 7315, pp. 555-561.

Wall, R., Devine-Wright, P. and Mill, G.A. (2007), "Comparing and combining theories to explain proenvironmental intentions: the case of commuting-mode choice", Environment and Behavior, Vol. 17 July, pp. 731-753.

Walters, A. (1989), “A life philosophy”, American Economist, Vol. 33 No. 2, pp. 18-24.

Watkins, K. (2006), "Human Development Report 2006-Beyond scarcity: power, poverty and the global water crisis", UNDP Human Development Reports (2006), p. 127.

WFP (2016), "Annual evaluation report”, available at: https://docs.wfp.org/api/documents/WFP0000015605/download/?_ga =2.243067521.206610007.1629752264-1272655237.1629752264.

Williams, H., Wikström, F., Otterbring, T., Löfgren, M. and Gustafsson, A. (2012), "Reasons for household food waste with special attention to packaging", Journal of Cleaner Production, Vol. 24, pp. 141-148.

Yeomans, M. (2012), "Using social media to raise consumer awareness on water scarcity", available at: https://www.theguardian.com/sustainable-business/social-media-consumer-awareness-waterscarcity.

Yount, R. (2006), "Populations and sampling”, DR Yount, Research Design and Statistical Analysis for Christian Ministry, (Chapter 7), p. 278. 
Zhai, X., Wang, M. and Ghani, U. (2019), "The SOR (stimulus-organism-response) paradigm in online learning: an empirical study of students' knowledge hiding perceptions", Interactive Learning Environment, Vol. 28 No. 5, pp. 586-601.

Zhang, S.J., Peng, Y.Z., Wang, S.Y., Zheng, S.W. and Jin, G.U.O. (2007), "Organic matter and concentrated nitrogen removal by shortcut nitrification and denitrification from mature municipal landfill leachate", Journal of Environmental Sciences, Vol. 19 No. 6, pp. 647-651.

Zhang, J., Zhang, C.L., Shi, W.L. and Fu, Y.C. (2019), "Quantitative evaluation and optimized utilization of water resources-water environment carrying capacity based on nature-based solutions", Journal of Hydrology, Vol. 568, pp. 96-107.

\section{Corresponding author}

Jari Salo can be contacted at: jari.salo@helsinki.fi

For instructions on how to order reprints of this article, please visit our website:

www.emeraldgrouppublishing.com/licensing/reprints.htm

Or contact us for further details: permissions@emeraldinsight.com

Measurement of consumer awareness of food waste 